Mavi Atlas, 9(1)2021: 132-146

Makale Geliș | Received: 27.11.2020.

Makale Kabul | Accepted: 24.12.2020.

DOI: $10.18795 /$ gumusmaviatlas. 832657

Gülin YAZICI ÇELEBİ

Dr. Öğr. Üyesi| Assist. Prof. Dr. Gümüşhane Üniversitesi, Edebiyat Fakültesi, Psikoloji Bölümü, Gümüşhane -TÜRKIYE Gumushane University, Faculty of Letters, Department of Psychology, Gumushane-TURKEY

ORCID: 0000-0002-6779-9123

gycelebi@gumushane.edu.tr

\title{
Kadınların Kişilik Özellikleri ile Psikolojik Sağlamlık Düzeyleri Arasındaki İlişkinin İncelenmesi
}

Öz

Üzerinde uzlaşılmış bir tanımı olmamasına rağmen kişilik, yüzyıllardır incelenen bir konudur. Farklı boyutlarda ele alınmakla beraber daha çok kişilik, belirli özelliklerin gösterilip gösterilmemesi ile sınıflandırılmaya çalışılmaktadır. Hangi kişilik özelliğinin hangi davranışlara ya da yaşam becerilerine yatkınlık oluşturduğu da ayrıca incelenmeye açık bir konudur. Bu araştırmanın amacı da bireylerin kişilik özellikleri ile psikolojik sağlamlık düzeyleri arasındaki ilişkinin incelenmesidir. İlişkisel tarama modeli kullanılan araştırmanın çalışma grubunu 18 yaş üstü 312 kadın oluşturmaktadır. Çalışma grubunun yaş ortalaması 33,6 olarak hesaplanmıştır. Araştırmaya katılım, gönüllülük esasına göre sağlanmış ve basit örnekleme yöntemi ile 2019 yılında toplanmıştır. Veri toplama araçları için gereken izinler alınmıştır. Veri toplama aracı olarak Cervantes Kişilik Ölçeği ile Kısa Psikolojik Sağlamlık Ölçeği kullanılmıştır. Ayrıca araştırmacı tarafından hazırlanan kişisel bilgi formu ile çalışma grubuna ilişkin demografik bilgiler toplanmıştır. Elde edilen veriler, SPSS 25 programında analiz edilmiştir. Yapılan normallik analizlerinden sonra uygulanacak tekniklere karar verilmiş, değişkenler arasındaki ilişkilerin analizinde Pearson korelasyon tekniği, ikili değişkenlerin karşılaştırılmasında t-testi, üç ve daha fazla kategorili değişkenlerde ise tek yönlü varyans analizi kullanılmıştır. Farkın kaynağını belirlemek için Bonferroni testinden yararlanılmıştır. Yapılan analizler sonucunda psikolojik sağlamlık ile kişilik özellikleri alt boyutları arasında anlamlı ilişkiler olduğu; yaş, medeni durum, eğitim düzeyi, bir işte çalışıp çalışmama durumu açısından da anlamlı farklılıklar olduğu belirlenmiştir. Elde edilen veriler, alanyazın ışı̆̆ında tartışılmıştır.

Anahtar Kelimeler: Kişilik Özellikleri, Psikolojik Sağlamlık, Kadın.

\section{Analysis of the Relationship Between Women's Personality Traits and Psychological Resilience Levels}

\begin{abstract}
Although it has no agreed definition, personality has been an issue that has been studied for centuries. Although it is handled in various dimensions, personality is rather tried to be classified by whether it shows or does not show certain characteristics. Which personality trait predisposes to which behaviours or life skills is also a subject open to research. The aim of this study is to examine the relationship between individuals' personality traits and their psychological resilience. The sample group of the study used in the correlational survey model consists of 312 women over 18 years of age. Participation in the research was on a voluntary basis and was collected in 2019 with the simple sampling method. Necessary permissions have been obtained for data collection tools. The Cervantes personality scale and the short psychological resilience scale were used as data collection tools. In addition, demographic information about the study group was collected with the personal information form prepared by the researcher. The data obtained were analyzed through the SPSS 23 program. After the normality analysis, the techniques to be applied were decided. Pearson correlation technique was used in the analysis of the relationships between variables, the t-test for the comparison of binary variables, and one-way variance analysis was used for variables with three or more categories. A Bonferroni test was used to determine the source of the difference. As a result of the analysis, it was determined that there is a significant relationship between psychological resilience and personality traits sub-dimensions and that there are also significant differences in regards to age, marital status, education level, and whether working or not. The discussion is based on the analysis of the obtained data.
\end{abstract}

Keywords: Personality Traits, Psychological Resilience, Woman. 


\section{Giriş}

Günlük dilde sıkça karşımıza çıkan kişilik kavramı, bireyin temel özelliklerini içeren görece sürekli bir yapıyı ifade etmektedir. Kişiliğin ne olduğu ile ilgili tanımlama çalışmaları ilkçă̆ filozoflarından günümüze kadar gelmesine rağmen üzerinde uzlaşılmış tek bir tanım söz konusu değildir. Kelimenin kökleri Latincedeki persona kavramına dayanmakta ve tiyatro oyuncularının yüzlerine taktıkları maskelerle üstlendikleri rolleri ifade etmektedir (Yanbast1, 1990: 9). Kişilik kavramı, çok boyutludur ve alan yazında farklı boyutlara vurgu yapan çok fazla tanımlama olduğu görülmektedir. Kişilik ile ilgili temel tanımlardan birinin sahibi olan Allport (1961) kişiliği; bireyin kendine özgü düşünce, davranış ve his kalıbını üreten, psikolojik sistemin insan içindeki dinamik bir organizasyonu olarak tanımlamıştır (Carver and Scheier, 2008: 5). Tanıma bakıldığında kişiliğin duygu, düşünce ve davranış boyutuna vurgu yaptığı görülmektedir ve bu durum bireyin varliğının bütününü kapsadığ1 şeklinde yorumlanabilir. Burger (2006) ise kişiliği bireyin kendisinden kaynaklanan tutarlı davranış kalıpları ve kişilik içi süreçler olarak tanımlamaktadır. Bu tanımlamada ise tutarlılık ve devamllık boyutuna dikkat çekilmektedir, bir başka değişle durumsal anlık tepkilerden ziyade devamlılık ve tutarlılık içeren bir yapıdan söz edilmektedir. Benzer hususlara dikkat çeken başka bir tanımda ise Flett (2007) kişiliğin hayatın ilk yıllarından itibaren kendini gösteren, duruma ve zamana göre genellenebilen özellikleri de içeren, görece değişmez bireysel farklılıklar olarak tanımlamaktadır. Köknel (2005) ise kişiliği bireyin çevresi ile uyum sağlamak amacıyla gösterdiği davranışların tamamı ayrıca bireyi diğerlerinden farklılaştıran psikolojik, fizyolojik ve zihinsel nitelikler olarak açıklamaktadır. Bireysel farklılıklara vurgu yapan başka bir tanımlamada ise Cüceloğlu (2012) kişiliği; bireyin iç ve dış çevresiyle kurduğu, diğer bireylerden ayırt edici, tutarlı ve yapılaşmış bir ilişki biçimi olarak tanımlamaktadır. İnsanların olaylara bakış açıları, olayları yorumlama biçimi olaylar sonrası yaşadıkları duygular ve düşünceleri birbirinden farklılıklar göstermektedir. Bu farklılıkların temel kaynağının kişilik olduğu söylenebilir. Bireylerin aynı olaylara farklı tepkiler vermeleri, farklı düzeylerde etkilenmelerinin kişilikle ilişkili olduğu söylenebilir. Kişilikle ilgili çalışmalarıyla bilinen Alport'a göre bireylerin davranışlarının en temel belirleyicisi kişilik yapılarıdır ve benzer olaylara farklı tepkiler verilmesi de bu durumla ilişkilendirilmektedir (Burger, 2006). "Yumurtayı pişiren güneş, yağı eritir." sözü bu görüşlerin kısa bir özeti kabul edilebilir. Kısaca ifade etmek gerekirse bireyin kişiliğinin yaşam olaylarına vereceği tepkiyi etkileyeceği söylenebilir. Benzer olayları yaşayan insanların bazıları hemen pes edebilirken bazıları daha mücadeleci yaklaşımlar gösterebilmektedirler, maruz kaldıkları değişikliklere bazıları kolay uyum gösterebilirken bazıları uyum sorunları yaşayabilmektedir. Bu durum akla psikolojik sağlamlık kavramını getirmektedir. Psikolojik sağlamlık kavramı köklerini Latincedeki "resiliens" kelimesinden almaktadır, kelime anlamı organizmanın yaşanan bir değişim sonrasında yeniden eski dengesine dönmesidir (Greene, 2002: 12). Pozitif psikolojinin önemli kavramlarından biri olan psikolojik sağlamlık bireyin yaşadığı zorluklar karşısında sergilediği başa çıkma becerisi ve uyum olarak tanımlanmaktadır (Block and Kremen, 1996). Fraser et al. (1999) ise benzer bir şekilde psikolojik sağlamlı̆̆1 olumsuz yaşam olaylarına rağmen pozitif kalma ve beklenmeyen durumlara kolay uyum sağlama becerisi olarak tanımlamaktadırlar. Uyum becerisine vurgu yaptığ1 tanımlamalarında Masten ve Coatsworth (1998), psikolojik sağlamlık kavramını risk durumları karşısında uyum ve gelişmeyi sağlayan yetkinlik olarak tanımlamışlardır. Bazı araştırmacılar, psikolojik sağlamlı̆̆ın bireyin kişilik özelliklerinden gelen bir olgu olduğuna vurgu yapmaktadır (Jacelon, 1997: 124). Alan yazına bakıldığında psikolojik sağlamlık ile ilişkilendirilebilecek çok sayıda özellik olduğu görülmektedir. Öz sayg1, olumlu duygusallık, umut, iyimserlik psikolojik sağlamlık bunlardan bir kaçıdır (Luthar et al., 2000: 547). Psikolojik sağlamlık ve kişilik özelliklerinin farklı değişkenlerle birlikte ele alındığı birçok çalışma aralarındaki ilişkiyi ortaya koymaktadır (Çetin vd., 2015; Fayombo, 2010; Friborg et al., 2005; Liu et al., 2012). Psikolojik sağlamlık yaşam olayları karşısında gösterilecek yaklaşım, etkilenme düzeyi ve neticesinde oluşacak sonuçlar üzerinde etkilidir. Kişilik özellikleri ile ilişkisinin ortaya konmasının, geliştirilebilecek bir özellik olan 
YAZICI ÇELEBİ, Gülin (2021). “Kadınların Kişilik Özellikleri ile Psikolojik Sağlamlık Düzeyleri Arasındaki İlişkinin İncelenmesi”, Mavi Atlas, 9(1): 132 - 146

psikolojik sağlamlık üzerinde yapılacak çalışmalara katkı sağlayacağı söylenebilir. Alanyazında yapılan çalışmalarda psikolojik sağlamlık düzeyinin cinsiyete göre farklılaştı̆̆ına ve erkeklerin psikolojik sağlamlık düzeylerinin daha yüksek olduğunu gösteren çok sayılda araştırma bulgusu olduğu görülmektedir (Açıkgöz, 2016; Aydın vd., 2019; Bahadır, 2009; Boyraz ve Sayger, 2011; Deniz vd., 2020; Dolbier et al., 2007; Erdoğan, 2015; Erkoç ve Danıs, 2020; Hoşoğlu, 2018; Karakış, 2019; Kodaz vd., 2018; Sarwar et al.,2010; Taşğın vd., 2017; Toprak, 2014; Yılmaz-Irmak, 2011). Kadınların psikolojik sağlamlık düzeylerinin incelenmesinin bu durumun sebeplerini belirleme sürecine katkı sağlayacağı düşünülmektedir. Psikolojik sağlamlık konusunda sadece kadınlar üzerinde yapılmış araştırmaların sayısının sınırlı olması nedeniyle böyle bir çalışmanın alana katkı sağlayacağı düşünülmektedir. Bu araşıırmanın amacı kadınların kişilik özellikleri ile psikolojik sağlamlık düzeyleri arasındaki ilişkinin incelenmesidir.

\section{Yöntem}

\section{Araştırmanın Deseni}

Araştırmada nedensel karşılaştırma yöntemi kullanılmıştır. Nicel araştırma yöntemlerinden biri olan nedensel karşılaştırmada bir durumun ya da olayın nedenlerini, sebep ya da sonuçların nelerden kaynaklandığını, bu nedenleri etkileyen değisskenleri ve değişkenler arasındaki ilişkinin varlığının belirlenmeye çalışıldığı bir araştırma yöntemidir (Metin, 2014).

\section{Çalışma Grubu}

Araştırmanın çalısma grubu 18 yaş üstü kadınlardan oluşmaktadır. Araştırmaya toplam 319 kişi katılmış eksik ve hatalı olan formlar iptal edildikten sonra 312 kişilik bir veri seti elde edilmiştir. Araştırmaya katılım gönüllülük esasına göre sağlanmış, verilerin toplanmasında basit rastgele örnekleme yöntemi kullanılmıştır. Bu örnekleme aracilığıyla yapılan seçimlerde evrendeki tüm birimlerin örnekleme seçilmek için eşit ve bağımsız bir şansa sahip oldukları bildirilmiştir (Büyüköztürk vd., 2014; Fraenkel et al., 2012).

Tablo 1. Araştırmanın Çalışma Grubuna İlişkin Bilgiler

\begin{tabular}{llll} 
& & $\mathrm{F}$ & $\%$ \\
\hline Medeni & Bekâr & 191 & 61 \\
Durum & Evli & 121 & 39 \\
\hline \multirow{3}{*}{ Yaş } & $18-25$ & 103 & 33 \\
& $25-35$ & 82 & 26 \\
& $35-45$ & 54 & 18 \\
\hline \multirow{2}{*}{ Eğitim } & 45 üstü & 73 & 23 \\
Düzeyi & Lise & 125 & 40 \\
\multirow{2}{*}{ Çalş̧an } & Üniversite & 187 & 60 \\
\hline
\end{tabular}

\section{Veri Toplama Araçları}

\section{Cervantes Kişilik Ölçeği (CKÖ)}

Ölçek kadınların benlik özelliklerini belirlemek amacıyla Castelo-Branco ve arkadaşları (2008) tarafindan geliştirilmiş ve Türkçe uyarlama çalışmaları Bal ve Şahin (2011) tarafindan yapılmıştır. Altılı likert tipindeki ölçekte 20 madde ve üç alt boyut bulunmaktadır. Alt boyutlar içe/dışa dönük olma, nörotizim/ duygusal denge ve tutarlı/tutarsız olma şeklindedir. İçe/dışa dönük olma alt boyutunda düşük puan dişadönük olma, yüksek puan içedönük olma, nörotizm/duygusal denge alt boyutunda alınan düşük puan duygusal denge yüksek puan nörotizm, 
YAZICI ÇELEBİ, Gülin (2021). “Kadınların Kişilik Özellikleri ile Psikolojik Sağlamlık Düzeyleri Arasındaki İlişkinin İncelenmesi”, Mavi Atlas, 9(1): 132 - 146

tutarll1ık/tutarsızlık alt boyutunda alınan düşük puan tutarlılığa yüksek puan tutarsızlığa işaret etmektedir. Ölçeğin içe/dişa dönük olma boyutu için güvenirlik katsayısı $\alpha=.97$; nörotizm/duygusal denge için $\alpha=.81$; tutarlı/tutarsız olma için $\alpha=.71$ 'dir (Şener, 2017). Ölçeğin bu araştırma için hesaplanan Cronbach Alpha katsayıları içe/dışa dönük olma için .74, nörotizm/duygusal denge için .77 ve tutarlı/tutarsız olma için .81 olarak tespit edilmiştir.

\section{Kısa Psikolojik Sağlamlık Ölçeği (KPSÖ)}

Ölçeğin Türkçe uyarlaması, Doğan (2015) tarafindan yapılmıştır. Ölçeğin orjinali Smith et al. (2008) tarafından geliştirilmiştir. Toplam altı maddeden oluşan beşli likert tipi ölçekten alınan yüksek puan psikolojik sağlamlık düzeyinin yüksek olduğu anlamına gelmektedir. Doğan (2015) tarafindan yapılan çalışmada ölçeğin iç tutarlık katsayısı .83; bu araştırmada ise .81 olarak bulunmuştur.

\section{Kişisel bilgi formu}

Araştırmacı tarafindan hazırlanan kişisel bilgi formu, çalışma grubunun demografik bilgilerine yönelik (yaş, medeni durum, eğitim düzeyi, gelir getiren bir işte çalışıp çalışmama) sorulardan oluşmaktadır.

\section{Verilerin Toplanmas1}

Ölçekler için gerekli kullanım izinleri alınmış ve veriler 2019 yllında google form uygulaması ile toplanmıştır.

\section{Veri Analizi}

Verilerin analizinde SPSS 25 programı kullanılmıştır. Normallik analizleri yapıldıktan sonra kullanılacak analiz teknikleri belirlenmiştir. Tablo 2 incelendiğinde, değişkenlere ilişkin çarpıklık değerlerinin ilgili alanyazında ölçüt olarak kabul edilen basıklık ve çarpıklık değerleri +2 ile -2 arasında olmasının normallik varsayımının karşılandığını göstermektedir (George and Mallery, 2019). Değişkenler arasındaki ilişkilerin belirlenmesinde Pearson Korelasyon tekniği, iki kategorili değişkenlerde t-testi; 3 ve daha fazla kategori olanlarda tek yönlü varyans analizi kullanılmıştır. Farkın kaynağını belirlemek amacıyla Bonfferoni testi kullanılmıştır.

Tablo 2. Ölçme Araçlarına İlişkin Çarpıklık ve Basıklık Katsayıları

\begin{tabular}{|c|c|c|c|c|c|c|c|c|c|}
\hline & \multirow[t]{2}{*}{$\mathrm{N}$} & \multirow[t]{2}{*}{ Min. } & \multirow[t]{2}{*}{ Mak. } & \multirow[t]{2}{*}{ Ort. } & \multirow{2}{*}{$\begin{array}{l}\text { Std. } \\
\text { Sapma }\end{array}$} & \multicolumn{2}{|c|}{ Çarpıklık } & \multicolumn{2}{|c|}{ Basılklik } \\
\hline & & & & & & Değer & Hata & Değer & Hata \\
\hline D1şadönüklük/İçedönüklük & 312 & 1.00 & 29.00 & 13.45 & 5.41 & .33 & .14 & .01 & .28 \\
\hline Denge/Nörotizm & 312 & 1.00 & 35.00 & 17.66 & 6.75 & .02 & .14 & -.52 & .28 \\
\hline Tutarlılık/Tutarsızlık & 312 & 3.00 & 30.00 & 19.28 & 4.88 & -.37 & .14 & -.24 & .28 \\
\hline Psikolojik Sağlamlık & 312 & 6.00 & 30.00 & 19.11 & 4.47 & -.12 & .14 & .18 & .28 \\
\hline
\end{tabular}

\section{Bulgular}

Tablo 3. Psikolojik Sağlamlık ile Kişilik Özellikleri Arasındaki İlişkiye Yönelik Korelasyon Analizi

\begin{tabular}{|c|c|c|c|c|}
\hline & 1 & 2 & 3 & 4 \\
\hline 1. Dişadönüklük/İçedönüklük & 1 & & & \\
\hline 2. Denge / Nörotizm & $.14^{*}$ & 1 & & \\
\hline 3. Tutarlılık / Tutarsızlık & .01 & $-.51 * *$ & 1 & \\
\hline 4. Psikolojik Sağlamlık & $.32 * *$ & $-.51 * *$ & $.17 *$ & 1 \\
\hline
\end{tabular}

Tablo 3'e bakıldığında psikolojik sağlamlık ile kişilik özellikleri alt boyutları arasında anlamlı ilişkiler olduğu görülmektedir. En güçlü ilişki psikolojik sağlamlık ile denge/nörotizm alt boyutu arasındaki ters yönlü ilisskidir $\left(\mathrm{r}=-.51^{* *}\right)$. Psikolojik sağlamlık ile dişadönüklük arasında $\left(\mathrm{r}=.32^{* *}\right)$; tutarlılık arasında $\left(\mathrm{r}=.17^{*}\right)$ düzeyinde anlamlı ilişki vardır. Bir başka deyişle bireylerin psikolojik sağlamlık 
YAZICI ÇELEBİ, Gülin (2021). “Kadınların Kişilik Özellikleri ile Psikolojik Sağlamlık Düzeyleri Arasındaki İlişkinin İncelenmesi”, Mavi Atlas, 9(1): 132 - 146

düzeyleri yükseldikçe nörotizm düzeyleri düşmektedir. Ayrıca psikolojik sağlamlık düzeyi yüksek kadınların dışadönüklük düzeyleri de yükselmektedir.

Tablo 4. Kadınların Kişilik Özelliklerinin Medeni Durum Açısından İncelenmesine Yönelik İlişkisiz Örneklemler T-Testi Sonuçları

\begin{tabular}{lllllll} 
& Medeni Durum & $\mathrm{N}$ & $\overline{\mathrm{X}}$ & $\mathrm{S}$ & $\mathrm{t}$ & $\mathrm{p}$ \\
\hline $\begin{array}{l}\text { Dişadönüklük/ } \\
\text { İçedönüklük }\end{array}$ & Bekar & 191 & 13.59 & 5.70 & .57 & .56 \\
\cline { 2 - 5 } & Evli & 121 & 13.23 & 4.94 & & \\
\hline $\begin{array}{l}\text { Denge/ } \\
\text { Nörotizm }\end{array}$ & Bekar & 191 & 19.21 & 6.67 & 5.28 & .00 \\
\cline { 2 - 5 } & Evli & 121 & 15.23 & 6.16 & 4.96 & .00
\end{tabular}

$\overline{\mathrm{p}<.01}$

Tablo 4'e bakıldığında medeni durum açısından anlamlı farklılıklar olduğu görülmektedir. Evli kadınların denge/nörotizm alt boyutundan ( $\mathrm{x}=15.23)$ aldıkları puan ortalamları bekar kadınlardan daha düşüktür $(\mathrm{x}=19.21)$ ve aralarındaki farkın anlamlı olduğu görülmektedir $(\mathrm{t}(310)=5.28$; $\mathrm{p}<.01)$. Kişilik özelliğinin tutarlılık/tutarsızlık alt boyutunda ise bekar kadınların puan ortalamları $(\mathrm{x}=18.31)$ evli kadınlardan $(\overline{\mathrm{x}}=20.82)$ daha yüksektir ve aralarındaki fark anlamlıdır $(\mathrm{t}(310)=4,56$; $\mathrm{p}<.01)$.

Tablo 5. Kadınların Psikolojik Sağlamlık Düzeylerinin Medeni Durum Açısından İncelenmesine Yönelik İlişkisiz Örneklemler T-Testi Sonuçları

\begin{tabular}{lcccccc}
\multicolumn{2}{c}{ Medeni Durum } & $\mathrm{N}$ & $\overline{\mathrm{X}}$ & $\mathrm{Ss}$ & $\mathrm{t}$ & $\mathrm{p}$ \\
\hline $\begin{array}{l}\text { Psikolojik } \\
\text { Sağlamlık }\end{array}$ & Bekâr & 191 & 18.71 & 4.76 & & \\
& Evli & 121 & 19.77 & 3.94 & & .04
\end{tabular}

$* \mathrm{p}<.05 \quad * * \mathrm{p}<.01$

Tablo 5’te yer alan sonuçlara göre kadınların psikolojik sağlamlık düzeyleri medeni durum açısından farklılaşmaktadır. Evli kadınların psikolojik sağlamlık düzeyleri $(\mathrm{x}=19.77)$ bekâr kadınlardan $(\bar{X}=18.71)$ daha yüksek olarak bulunmuştur ve aralarındaki fark anlamlıdır $(\mathrm{t}(310)=2.05 ; \mathrm{p}<.05)$.

Tablo 6 Kadınların Kişilik Özellikleri ve Psikolojik Sağlamıı Ölçeklerinden Aldıkların Puanların Yaş Değişkeni Açısından İncelenmesine Yönelik Betimsel İstatistikler

\begin{tabular}{|c|c|c|c|c|}
\hline & Yaş & $\mathrm{N}$ & $\mathrm{X}$ & Ss \\
\hline \multirow{4}{*}{ Dişadönüklük / İçedönüklük } & $18-25$ & 103 & 13.82 & 6.02 \\
\hline & $25-35$ & 82 & 13.20 & 4.99 \\
\hline & $35-45$ & 54 & 12.96 & 4.93 \\
\hline & 45 yaş üstü & 73 & 13.83 & 5.52 \\
\hline \multirow{4}{*}{ Denge / Nörotizm } & $18-25$ & 103 & 20.03 & 6.23 \\
\hline & $25-35$ & 82 & 18.80 & 7.06 \\
\hline & $35-45$ & 54 & 15.50 & 5.66 \\
\hline & 45 yaş üstü & 73 & 14.78 & 6.11 \\
\hline \multirow{4}{*}{ Tutarlılık Tutarsızlık } & $18-25$ & 103 & 18.07 & 5.02 \\
\hline & $25-35$ & 82 & 18.49 & 5.09 \\
\hline & $35-45$ & 54 & 20.56 & 4.00 \\
\hline & 45 yaş üstü & 73 & 21.00 & 4.36 \\
\hline \multirow{4}{*}{ Psikolojik Sağlamlık } & $18-25$ & 103 & 18.58 & 4.68 \\
\hline & $25-35$ & 82 & 18.71 & 4.91 \\
\hline & $35-45$ & 54 & 19.83 & 3.79 \\
\hline & 45 yaş üstü & 73 & 19.53 & 4.19 \\
\hline
\end{tabular}


YAZICI ÇELEBİ, Gülin (2021). “Kadınların Kişilik Özellikleri ile Psikolojik Sağlamlık Düzeyleri Arasındaki İlişkinin İncelenmesi”, Mavi Atlas, 9(1): 132 - 146

Tablo 7. Kadınların Kişilik Özelliklerinin Yaş Değişkeni Açısından İncelenmesine Yönelik Tek Yönlü Varyans Analizi Sonuçları

\begin{tabular}{|c|c|c|c|c|c|c|c|}
\hline & & K.T & $\mathrm{Sd}$ & K.O & F & $p$ & İkili Karş. \\
\hline \multirow{3}{*}{$\begin{array}{l}\text { Dişadönüklük/ } \\
\text { İçedönüklük }\end{array}$} & Gruplararas1 & 33.308 & 3 & 11.103 & \multirow{3}{*}{0.37} & \multirow{3}{*}{.77} & \\
\hline & Grup İçi & 9089.970 & 308 & 29.513 & & & \\
\hline & Toplam & 9123.279 & 311 & & & & \\
\hline \multirow{3}{*}{$\begin{array}{l}\text { Denge/ } \\
\text { Nörotizm }\end{array}$} & Gruplararas1 & 1595.604 & 3 & 531.868 & \multirow{3}{*}{13.01} & \multirow{3}{*}{.00} & \multirow{3}{*}{$4 / 1-2-3$} \\
\hline & Grup İçi & 12593.729 & 308 & 40.889 & & & \\
\hline & Toplam & 14189.333 & 311 & & & & \\
\hline \multirow{3}{*}{$\begin{array}{l}\text { Tutarlılık/ } \\
\text { Tutarsızlık }\end{array}$} & Gruplararas1 & 493.053 & 3 & 164.351 & \multirow{3}{*}{7.30} & \multirow{3}{*}{.00} & \multirow{3}{*}{$4 / 1-2-3$} \\
\hline & Grup İçi & 6928.126 & 308 & 22.494 & & & \\
\hline & Toplam & 7421.179 & 311 & & & & \\
\hline
\end{tabular}

* $\mathrm{p}<.05 * * \mathrm{p}<.01$

Tablo 7’ye bakıldığında kadınların kişilik özelliklerinin yaş değişkeni açısından incelendiği ANNOVA testi sonuçları görülmektedir. Yaş değişkeninin kişilik özellikleri alt boyutlarından dışadönüklük/içedönüklük boyutlarında anlamlı bir fark oluşturmadığ 1 ( $>>$.05) ancak denge/nörotizm $(\mathrm{F}(3 ; 308)=13.01 ; \mathrm{p}<.01)$ ve tutarll1k/ tutarsızlı $(\mathrm{F}(3 ; 308)=7.30 ; \mathrm{p}<.01)$ alt boyutlarında anlamlı farklılıklar olduğu görülmektedir. Farkın kaynağını belirlemek amacıyla yapılan Bonferroni testine göre farkın kaynağı her ikisinde de 45 yaş üstü kadınlarla diğer yaş grupları arasındaki farktır. 45 yaş üstü kadınların hem denge /nörotizm puanları hem de tutarlılık/tutarsızlık alt boyutlarındaki puan ortalamaları diğer yaş gruplarından daha düşüktür.

Tablo 8. Kadınların Psikolojik Sağlamlık Düzeylerinin Yaş değişkeni Açısından İncelenmesine Yönelik Tek Yönlü Varyans Analizi Sonuçları
K.T
K.O
F p

\begin{tabular}{|c|c|c|c|c|c|c|}
\hline \multirow{2}{*}{$\begin{array}{l}\text { Psikolojik } \\
\text { Sağlamlık }\end{array}$} & Gruplar aras 1 & 105.773 & 3 & 35.258 & \multirow{2}{*}{1.77} & \multirow{2}{*}{.15} \\
\hline & Grup İçi & 6134.839 & 308 & 19.918 & & \\
\hline & Toplam & 6240.612 & 311 & & & \\
\hline
\end{tabular}

$\mathrm{p}<\overline{.05}$

Tablo 8'de kadınların psikolojik sağlamlık düzeylerinin yaş değişkeni açısından farklılaşıp farklılaşmadığını belirlemek amacıyla yapılan Annova testi sonuçları görülmektedir. Yapılan analizler sonucunda yaş değişkeni açısından anlamlı bir fark olmadığı görülmektedir $(\mathrm{F}(3 ; 308)=1.77$; $\mathrm{p}>.05)$

Tablo 9. Kadınların Kişilik Özelliklerinin Eğitim düzeyi açısından incelenmesine Yönelik İlişkisiz Örneklemler T-Testi Sonuçları

\begin{tabular}{lllllll} 
& & $\mathrm{N}$ & $\overline{\mathrm{X}}$ & $\mathrm{S}$ & $\mathrm{T}$ & $\mathrm{p}$ \\
\hline $\begin{array}{l}\text { Dişadönüklük/ } \\
\text { İçedönüklük }\end{array}$ & Lise & 125 & 14.26 & 5.87 & \multirow{2}{*}{2.17} & .03 \\
\cline { 2 - 7 } & Üniversite & 187 & 12.91 & 5.03 & 6.91 & \multirow{2}{*}{01} \\
\hline $\begin{array}{l}\text { Denge/ } \\
\text { Nörotizm }\end{array}$ & Lise & 125 & 18.76 & 6.35 & .57 & .79
\end{tabular}


YAZICI ÇELEBİ, Gülin (2021). “Kadınların Kişilik Özellikleri ile Psikolojik Sağlamlık Düzeyleri Arasındaki İlişkinin İncelenmesi”, Mavi Atlas, 9(1): 132 - 146

$\begin{array}{llll}\text { Tutarsızlık } & \text { Üniversite } & 187 & 19.34\end{array}$

$* \mathrm{p}<.05 * * \mathrm{p}<.01$

Tablo 9'a bakıldığında kadınların kişilik özellikleri alt boyutlarından tutarlılı/tutarsızlık düzeylerinin eğitim düzeyi açısından farklılaşmadığı, dışadönüklük/içedönüklük $(\mathrm{t}(310)=2.17$; $\mathrm{p}<.05$ ) ve denge/ nörotizm alt boyutlarında $(\mathrm{t}=(310)=2.355 ; \mathrm{p}<.05)$ anlamlı farklar oluşturduğu görülmektedir. Puan ortalamalarına bakıldığında üniversite mezunlarının puanlarının her iki alt boyutta da daha düşük olduğu görülmektedir.

Tablo 10. Kadınların Psikolojik Sağlamlık Düzeylerinin Eğitim Düzeyi Açısından İncelenmesine Yönelik İlişkisiz Örneklemler T-Testi Sonuçları

\begin{tabular}{lllllll} 
& Eğitim Düzeyi & $\mathrm{N}$ & $\overline{\mathrm{X}}$ & $\mathrm{Ss}$ & $\mathrm{t}$ & $\mathrm{p}$ \\
\hline $\begin{array}{l}\text { Psikolojik } \\
\text { Sağlamlık }\end{array}$ & Lise & 125 & 18.74 & 4.57 & \multirow{2}{*}{1.23} & .21 \\
\cline { 2 - 6 } $\mathrm{p}<.05$ & Üniversite & 187 & 19.37 & 4.41 & \\
\hline
\end{tabular}

Tablo 10’a bakıldığında kadınların psikolojik sağlamlık düzeylerinin eğitim düzeyi açısından farklılaşmadı̆̆ı görülmektedir ( $\mathrm{t}(310)=1.23$; $\mathrm{p}>.05)$.

Tablo 11. Kadınların Kişilik Özelliklerinin Gelir Getiren Bir İşte Çalışıp Çalışmama Durumu Açısından İncelenmesine Yönelik İlişkisiz Örneklemler T-Testi Sonuçları

\begin{tabular}{|c|c|c|c|c|c|c|}
\hline & Çalışıyor mu? & $\mathrm{N}$ & $x$ & Ss & $\mathrm{t}$ & $p$ \\
\hline \multirow{2}{*}{$\begin{array}{l}\text { Dişadönüklük/ } \\
\text { İçedönüklük }\end{array}$} & Evet & 114 & 13.38 & 5.20 & \multirow{2}{*}{.18} & \multirow{2}{*}{.85} \\
\hline & Hayır & 198 & 13.49 & 5.55 & & \\
\hline \multirow{2}{*}{$\begin{array}{l}\text { Denge/ } \\
\text { Nörotizm }\end{array}$} & Evet & 114 & 15.31 & 6.03 & \multirow{2}{*}{4.84} & \multirow{2}{*}{.00} \\
\hline & Hayır & 198 & 19.03 & 6.79 & & \\
\hline \multirow{2}{*}{$\begin{array}{l}\text { Tutarlilık/ } \\
\text { Tutarsızlık }\end{array}$} & Evet & 114 & 20.11 & 4.33 & \multirow{2}{*}{1.27} & \multirow{2}{*}{.29} \\
\hline & Hayır & 198 & 18.81 & 5.13 & & \\
\hline
\end{tabular}

$* \overline{\mathrm{p}<.05} * * \mathrm{p}<.01$

Tablo 11'e bakıldığında bir işte çalışıp çalışmama durumu açsından kadınların kişilik özellikleri alt boyutlarından denge/nörotizm açısından anlamlı farklilıklar olduğu $(\mathrm{t}(310)=4.84 ; \mathrm{p}<.01)$, diğer alt boyutlar açısından anlamlı bir farklılık olmadığı görülmektedir ( $\mathrm{p}>.05)$. Araştırma sonuçlarına göre çalışan kadınların denge / nörotizm puanları çalışmayan kadınlardan daha düşük olarak belirlenmiştir.

Tablo 12. Kadınların Psikolojik Sağlamlık Düzeylerinin Gelir Getiren Bir İşte Çalışıp Çalışmama Durumu Açısından İncelenmesine Yönelik İlişkisiz Örneklemler T-Testi Sonuçları

Çalışıyor mu

\begin{tabular}{lllllll}
\hline Psikolojik & Evet & 114 & 19.50 & 3.95 & 1.14 & .25 \\
\cline { 2 - 5 } Sağlamlık & Hayır & 198 & 18.90 & 4.75 & & \\
\hline $\mathrm{p}<.05$ & & & & &
\end{tabular}

Tablo 12'ye bakıldığında kadınların psikolojik sağlamlık düzeylerinin gelir getiren bir işte çalışıp çalışmama açısından farklılaşmadığını görülmektedir ( $\mathrm{t}(310)=1.14 ; \mathrm{p}>.05)$.

\section{Sonuç ve Tartışma}

Araştırma sonuçları psikolojik sağlamlık ile kişilik özellikleri arasında anlamlı ilişkiler olduğunu ortaya koymaktadır. Bireylerin psikolojik sağlamlık düzeyleri nörotizm ile ters yönde ilişkili bulunmuştur. Başka bir ifade ile bireylerin psikolojik sağlamlık düzeyleri yükseldikçe nörotizmden uzaklaşıp duygusal dengeye yaklaşmaktadırlar. Benzer şekilde psikolojik sağlamlık ile dışadönüklük olumlu yönde ilişkili bulunmuştur yani dışadönük insanların psikolojik sağlamlık düzeyleri daha 
yüksektir. Alanyazına bakıldığında bu araştırma ile benzer sonuçlara ulaşan çok sayıda araştırma olduğu görülmektedir (Çetin vd. 2015; Fayombo, 2010; Friborg et al., 2005; Froutan et al., 2018; Kandemir, 2019; Nakaya et al., 2006; Oshio et al., 2018; Özer, 2013; Sahi and Raghavi, 2016; Sills et al., 2006; Topçu, 2017). Bu çalışmaların tamamında psikolojik sağlamlığın nevrotizmle ters yönlü, dışadönüklükle ise olumlu yönde ilişkili olduğu sonucuna ulaşılmıştır. Nörotizm ya da duygusal dengizlik daha çok olumsuz duygu durumla özdeşleştirilen bir kişilik özelliği olarak ifade edilmektedir. Anksiyete, gerginlik, depresyon gibi duygu durumlar bunlara örnek gösterilebilir. Bu açıdan bakıldığında olumlu duygu durumla ilişkilendirilen psikolojik sağlamlık kavramının nörotizmle ters yönde ilişkili olması, olumlu bir kişilik özellĭgi olan dışadönüklük ile pozitif yönde ilişkili olması beklenen bir durumdur. Alanyazında sadece kadınlara yönelik çalışmalar çok sınırlı olduğundan bu konuda yapılan diğer çalışmalarda ele alınmaktadır.

Yaş değişkeni açısından bir farklılaşma olup olmadığını belirlemek amacıyla yapılan analizler sonucunda kadınların psikolojik sağlamlık düzeylerinde anlamlı bir farklılaşma olmadığı belirlenmiştir. Alanyazında yer alan araştırmalarda bu konuda farklı sonuçlara ulaşıldığı görülmektedir. Kılıç (2014) yaptığ1 araştırma sonucunda yaşın psikolojik sağlamlığ1 yordadığ1 sonucuna ulaşmıştır. Çutuk, vd., (2017) ise sporcularla yürüttükleri çalışmada yaş ile psikolojik sağlamlık arasında ters yönlü bir ilişki olduğu sonucuna ulaşırken Atik (2013) ve Türker-Yıldız (2018) ise yaptıkları araştırmalarda tam tersi bir sonuca ulaşmış psikolojik sağlamlık ile yaş arasında pozitif yönde ve anlamlı ilişki tespit etmiştirler. Aydın ve Egemberdiyeva (2018) ise yürüttükleri çalışmada yaşın psikolojik sağlamlı̆̆1 yordadığ1 sonucuna ulaşmıştırlar. Bu araştırma ile benzer sonuçlara ulaşarak psikolojik sağlamlığın yaşa göre farklılaşmadığı sonucuna ulaşan araştırmalarda mevcuttur (Bayrakdaroğlu, 2014; Bektaş ve Özben, 2016; Bildirici, 2014; Chan, 2003; Genç, 2014; Gökmen, 2014; Kırımoğlu vd., 2012; Maddi vd., 2006; Sezgin, 2009, 2012; Tekin, 2011; Ülker-Tümlü ve Recepoğlu, 2013). Çiltaş'in (2019) konukevinde kalan kadınlarla yürüttüğü araştırma sonucunda yaş açısından anlamlı bir fark olmadığı sonucuna ulaşılmıştır. Yaş değisskeni açısından araştırmaların farklı sonuçlara ulaştıkları görülmektedir ve farklıllğın grupların özelliklerinden kaynaklandığı düşünülmektedir.

Kişilik özelliklerinin yaş değişkeni açısından incelenmesine yönelik yapılan analizler sonucunda kişilik özellikleri alt boyutlarından denge/nörotizm ve tuttarllık/tutarsızlık düzeylerinin yaşa göre farklılaştı̆̆ı, dışadönüklük/içedönüklük açısından ise farkın anlamlı olmadığı görülmektedir. Araştırmanın sonucuna göre 45 yaş üstü kadınların denge/nörötizm puanlarının ve tutarlılık/tutarsızlık puanlarının diğer yaş gruplarına göre daha düşük olduğu bulgulanmıştır. Kişilik ile ilgili yapılan birçok çalışmada değişken olarak ele alınan yaşa ilişkin birbirinden farklı sonuçlara ulaşıldığı görülmektedir. Bazı araştırma sonuçları yaşa göre kişilik özelliklerinin farklılaştığı sonucuna işaret ederken (Sevi, 2009; Şeker-Sır, 2016; Terrel et al., 2008), bazı araştırma sonuçları ise yaşın etkisinin olmadığ1 sonucuna ulaşmıştır (Doğar, 2013; Tekin, 2012; Ulucan ve Bahadır, 2011). Bu araştırmada kişilik özellikleri alt boyutlarından dışadönüklük/içedönüklük boyutlarında yaş açısından anlamlı bir fark olmadığı sonucuna ulaşılmıştır. Sevi (2009); Terrel, Hill and Nagoshi, (2008); Noyan ve Sertel-Berk (2007) de yürüttükleri araştırmalarda aynı sonuca ulaşmıştırlar. Denge/Nörotizm ve tutarlılık/tutarsızlık alt boyutlarında ise yaşa bağlı olarak anlamlı farklılaşmalar olduğu belirlenmiştir. Bu araştırma ile benzer olarak Çelebi ve Uğurlu (2014); Eysenck and Wilson, (2000); Tunç ve Aliyev (2015); Şeker-Sır (2016) da yürüttükleri çalışmalarda yaş ilerledikçe tutarlılık puanının düştüğü yani daha tutarlı davranışlar gösterildiği sonucuna ulaşmıştırlar. Tam tersi bir sonuca ulaşan Savi (2008) ise yaş düzeyi arttıkça kişilik olarak davranışsal sorunların arttığını ifade etmiştir. Şahin (2020) ise yaptığı çalışmada yaşın kişilik özellikleri üzerinde bir etkisinin olmadığ1 sonucuna ulaşmıştır. Araştırma sonuçları çoğunlukla yaşın denge/nörotizm ve tutarlılık/tutarsızlık boyutlarında yaş lehine sonuçlar ortaya koymaktadır bu durumun yaşantı zenginliği, yaşın sağladığı deneyimden ve olgunlaşmaya bağlı olduğu söylenebilir. 
Araştırma sonuçları kadınların medeni durumlarının psikolojik sağlamlık düzeyleri ile kişilik özellikleri alt boyutlarından denge / nörotizm ve tutarlılık/tutarsıllık boyutlarında anlamlı farkl11ıklar oluşturduğunu, içedönüklük/dışadönüklük alt boyutunda ise anlamlı farklılık oluşturmadığını göstermektedir. Sonuçlara bakıldığında durumun psikolojik sağlamlık ile denge/nörotizm boyutlarında evli kadınlar lehine, tutatllik/tutrsızlık alt boyutunda ise bekâr kadınlar lehine olduğunu ortaya koymaktadır. Alanyazına bakıldığında bu araştırma ile benzer sonuçlara ulaşarak evlilerin psikolojik sağlamlık düzeylerinin daha yüksek olduğu (Türker, 2018: 6970) sonucuna ulaşan araştırma bulguları olduğu gibi medeni durum açısından kadınların psikolojik sağlamlık düzeylerinin farklılaşmadığ1 sonucuna ulaşan araştırma bulgularının da olduğu görülmektedir (Çiltaş, 2019). Kişilik özellikleri alt boyutlarından tutarlılık/tutarsızlıkta sonuçların bekârlar lehine olduğu (Çıtak, 2020: 34) sonucuna ulaşan araştırma sonuçları olduğu görülmektedir. Evlilik ilişkisinin bireye duygusal destek sağladığı söylenebilir. Temel duygusal ihtiyaçlarının karşılanmasının ve olumsuz yaşam olayları karşısında eşinin ve çocuklarının desteğini hissetmenin evli kadınların daha kolay uyum sağlamasına ve başaçıkma noktasında daha az zorlanmasına katkı sağlayacağı söylenebilir. Kadınların psikolojik sağlamlık düzeylerinin bu durumdan olumlu etkileneceği ve bu durumun evli ve bekârlar arasındaki farkın kaynağı olduğu söylenebilir. Evlilik ilişkisine karar vermek ve sürdürmek belirli düzeylerde duygusal kararlılık/denge gerektiren hususlardır, ayrıca kişilerarası ilişkilerin nörotizmden olumsuz etkileneceği de düşünüldüğünde evli bireylerin nörotizm puanlarının düşük çıkması bu durumla ilişkilendirilebilir. Bunlara ek olarak nörotizm özelliği yüksek bireylerin evlilikten kaçınıyor olmaları da söz konusu olabilir bu durum ayrıca araştırilmaya değer bir konudur.

Araştırmada kadınların eğitim düzeyleri açısından psikolojik sağlamlık düzeylerinin farklılaşmadığı, kişilik özelliklerinden dışadönüklük/içedönüklük ve denge/ nörotizm alt boyutları açısından farklılaşırken tutarlılı/tutarsızlık alt boyutunda farkın anlamlı olmadığı sonucuna ulaşılmıştır. Araştırma sonucuna göre üniversite mezunu kadınların denge/nörotizm ve tutarlılık/tutarsızlık puanları lise mezunu kadınlardan daha düşük olarak bulunmuştur yani üniversite mezunları duygusal olarak daha dengeli ve tutarlıdır denilebilir. Alan yazına bakıldığında eğitim düzeyi açısından psikolojik sağlamlı̆̆ın değerlendirildiği araştırmalarda farklı sonuçlara ulaşıldığı görülmektedir. Araştırmalarda genellikle psikolojik sağlamlığın öğrenim durumu açısından farklılaştığı sonucuna ulaşıldığı görülmektedir (Bektaş ve Özben, 2016; Bildirici, 2014; Bonanno et al., 2006; Bonanno ve Mancin, 2008; Campbell-Sills et al., 2006; Gökmen, 2014; Guinn et al., 2009; Kırımoğlu vd., 2012; Selçuklu, 2013; Soyer vd., 2013; Tekin, 2011). Bu araştırmalar hem kadın hem erkek katılımcılarla yürütülen çalışmalardır, bu araştırmanın sonucunun farklı olmasının sadece kadın katılımcılarla yürütülüyor olmasından kaynaklanabileceği düşünülmektedir. Kişilik özellikleri ile ilgili ulaşılan sonuçlara benzer araştırma sonuçları olduğu görülmektedir. Çıtak (2020) kadınlarla yürüttüğü çalışmada üniversite mezunu kadınların duygusal denge/nörotizm alt boyut puan ortalamalarının ilkokul ve ortaokul mezunlarından daha düşük olduğu sonucuna ulaşmıştır. Doğar (2013); Göksal (2017) ve Oktay (2007) de yürüttükleri çalışmalarda eğitim düzeyi açısından anlamlı sonuçlara ulaşmıstırlar. Üniversite öğrenimi bireye yaşantı zenginliği sağlamakta, aileden uzakta geçirilen öğrencilik yılları bireye kendi kendine yetebilme becerisi kazandırmaktadır. Aileden uzakta olunması arkadaşlık ilişkilerini ve çevre ile etkileşim kurmayı zorunlu hale getirmekte zorunlu bir sosyalleşme nedeniyle bireyler daha dışadönük davranma zorunluluğu hissedebilmektedirler. Ayrıca üniversite eğitiminin kazandırdığı becerilerinde etkisi bu anlamda bireylere avantaj sağlayabilmektedir. Tüm bu faktörlerin aradaki fark üzerinde etkili olacağı düşünülmektedir.

Bir işte çalışıp çalışmama durumu açısından bir farklılaşma olup olmadığını belirlemek amacıyla yapılan analizler sonucunda psikolojik sağlamlığın farklılaşmadığı kişilik özelliklerinden ise sadece denge/ nörotizm alt boyutunda anlamlı bir fark oluştuğu bulgulanmıştır. Bu araşturma ile benzer olarak Bektaş ve Özben (2016) ve Bildirici (2014) de çalışıp çalışmamanın psikolojik sağlamlık açısından bir farklılık oluşturmadığı sonucuna ulaşmıştırlar. Kişilik özellikleri açısından ulaştığımız 
sonuca benzer bir şekilde Çıtak (2020) kadınlarla yürüttügü çalışmada ev hanımlarının nörotizm puanlarının çalışan kadınlardan daha yüksek olduğu ancak bu araştırmadan farklı olarak dışadönükülük boyutunda da anlamlı farklar olduğu sonucuna ulaşmıştır. İş hayatının kadınların aktif olmasını ve kendini işe yarar hissetmesini sağladığı, kendi kendine yetme duygusunun özgüven üzerinde olumlu etkisnin olduğu ve bu durumun duygusal denge açısından avantaj sağladığ1 söylenebilir. Ev kadınlarının sürekli ev işleri ile meşgul olmalarının düzenli ve doyurucu bir sosyal hayat sürdürme noktsında dezavantajlı oldukları, tespit edilen farklarda bu durumların etkili olduğu düşünülmektedir. $\mathrm{Bu}$ araştırma sınırlı sayıda bir örneklem grubuna uygulanmıştır, psikolojik sağlamlığın özellikle önem kazandığı meslek gruplarının (sağlık hizmeti verenler, emniyet menzupları vb) katılacağı ve daha geniş ölçekli gruplarda, farklı değişkenlerin (meslek, çocuk sahip olup olmama, kardeş sayısı, doğum sırası, anne-baba tutumları, bağlanma stilleri vb.) ele alınacağı ve psikolojik sağlamlığı yordayıcı çalışmaların yapılmasının alana katkı sağlayacağı düşünülmektedir. Konuyla ilgili boylamsal çalışmaların yapılmasının psikolojik sağlamlık üzerinde etkili faktörlerin ortaya koyulabilmesi için önemli görülmektedir. Psikolojik sağlamlı̆̆1 arttırmaya yönelik düzenlecek psikolojik destek programlarının teşvik edilmesi, deneysel çalışmalarla yeni programların geliştirilmesi önerilmektedir.

\section{Kaynakça}

AÇIKGÖZ, Mustafa (2016). Çukurova Üniversitesi Tıp Fakültesi Öğrencilerinin Psikolojik Sağlamlık ile Mizah Tarzları ve Mutluluk Düzeyi Arasındaki İlişkinin İncelenmesi (Yayımlanmamış Doktora Tezi). Çağ Üniversitesi, Sosyal Bilimler Enstitüsü, Mersin

ATİK, Emine L. (2013). Liseli Ergenlerde Bağlanma Stilleri ve Psikolojik Sağlamlık Düzeyleri Arasındaki İlişkide Öz-Yansıtma ve İçoörünün Rolü, (Yayımlanmamış Yüksek Lisans Tezi). İstanbul Bilim Üniversitesi Sosyal Bilimler Enstitüsü, İstanbul.

AYDIN, İbrahim; ÖNCÜ, Erman; AKBULUT, Vildan ve Sonnur KÜÇÜK KILIÇ (2019). "Öğretmen Adaylarında Boş Zaman Sıkılma Alg1sı ve Psikolojik Sağlamlık İlişkisi." Atatürk Üniversitesi Beden Eğitimi ve Spor Bilimleri Dergisi, 21(1), 1-15.

AYDIN, Merve ve Arzu EGEMBERDIYEVA (2018). "Üniversite Öğrencilerinin Psikolojik Sağlamlık Düzeylerinin İncelenmesi”, Türkiye Eğitim Dergisi, 3(1): 37-53.

BAHADIR, Emel (2009). Sağllkla İlgili Fakültelerde Eğitime Başlayan Öğrencilerin Psikolojik Sağlamlık Düzeyleri (Yayımlanmamış Yüksek Lisans Tezi). Hacettepe Üniversitesi Sağlık Bilimleri Enstitüsü, Ankara.

BAL, Meltem D. ve Nevin Şahin HOTUN (2011). “Cervantes Kişilik Ölçeğinin Türkçe'ye Uyarlanması: Geçerlik ve Güvenirlik Çalışması”, Hemşirelikte Eğitim ve Araştırma Dergisi, 8(1): 39-45.

BAYRAKDAROĞLU, Serdar (2014). Tekvandocuların Psikolojik Sağlamlık ve Öz-Anlayış Düzeylerinin Takım Sporcularıyla Karşılaştırılması, (Yayımlanmamış Yüksek Lisans Tezi), Muğla Sıtk1 Koçman Üniversitesi, Sağlık Bilimleri Enstitüsü, Muğla.

BEKTAŞ, Mahmut ve Şüheda ÖZBEN (2016) "Evli Bireylerin Psikolojik Dayanıklılık Düzeylerinin Bazı Sosyo-Demografik Değişkenler Açısından Incelenmesi." Manisa Celal Bayar Üniversitesi Sosyal Bilimler Dergisi, 14(1): 215-224.

BİLDİRİCI, Fatmagül (2014). Özel Eğitime Gereksinimi Olan Çocuğa Sahip Ailelerde Aile Yükü ile Psikolojik Dayanıklılık Arasındaki İlişki, (Yayımlanmamış Yüksek Lisans Tezi), Haliç Üniversitesi Sosyal Bilimler Enstitüsü, İstanbul.

BLOCK, J. \& A. M. KREMEN (1996). "IQ and Ego Resiliency: Conceptual and Empirical Connections and Separateness", Journal of Personality and Social Psychology, 70(2): 349-361.

BONANNO, G. A., \& A. MANCINI (2008). "The Human Capacity to Thrive in the Face of Potential Trauma", Pediatrics, 121: 369-375. 
BONANNO, G.A.; GALEA, S.; BUCCIARELLI, A. \& D. VLAHOV (2006), "Psychological Resilience After Disaster: The New York City in the aftermath of the September 11th terrorist attack", Psychological Science, 17(3): 181-186.

BOYRAZ, Güler \& Thomas V. Sayger (2011). Psychological Well-Being Among Fathers of Children With and Without Disabilities: The Role of Familiy Cohesion, Adaptability and Paternal Self-Efficacy. American Journal of Meins Health, 5(4), 286-296. Yayınlar1

BURGER, Jerry. M. (2006). Kişilik. çev. İnan Deniz Erguvan Sarıŏlu. İstanbul: Kaknüs

BÜYÜKÖZTÜRK, Şener; ÇAKMAK KILIÇ, Ebru; AKGÜN, Özcan E.; KARADENIZ, Şirin ve Funda DEMIREL. (2014). Bilimsel Araştırma Yöntemleri. Ankara: Pegem Akademi.

CAMPBELL, S. L.; COHAN, S.L., \& M.B. STEIN (2006), "Relationship of Resilience to Personality, Coping, and Psychiatric Symptoms in Young Adults", Behavior Research and Therapy, 44: 585-599.

CARVER, C. S. \& M. F. SCHEIER (2008). Perspectives on Personality. Needham Heights, MA: Allyn and Bacon.

CHAN, David W. (2003), "Hardiness and İts Role in the Stresburnout Relationship Among Prospective Chinese Teachers in Hong Kong", Teaching and Teacher Education, 19: 381-395.

CÜCELOĞLU, Doğan (2012). İnsan ve Davramısı, İstanbul: Remzi Kitabevi.

ÇETIN, Fatih; YELOĞLU, Hakkı O. ve Nejat BASIM (2015). "Psikolojik Dayanıklılı̆ın Açıklanmasında Beş Faktör Kişilik Özelliklerinin Rolü: Bir Kanonik İlişki Analizi”, Türk Psikoloji Dergisi, 30(75): 81-92.

ÇITAK, Tuba (2020). Kadınların Kişilik Özelliklerinin Premenstrual Sendroma Etkisi, (Yayımlanmamış Yüksek Lisans Tezi), Ordu Üniversitesi, Sağlık Bilimleri Enstitüsü, Ordu.

ÇİLTAŞ, Çağrı (2019). Kadın Konukevi Hizmeti Almakta Olan Kadınların Psikolojik Dayanıklılık ile Umut Düzeyleri Arasındaki İlişkinin İncelenmesi (Yayımlanmamış Yüksek Lisans Tezi) Ankara Yıldırım Beyazıt Üniversitesi Sağlık Bilimleri Enstitüsü, Ankara.

ÇUTUK, Selman; BEYLEROĞLU, Malik; HAZAR, Muhsin; ÇUTUK, Zeynep A. ve Şakir BEZCI (2017). Judo Sporcularının Psikolojik Dayanıklılık Düzeyleri ile Kayg1 Düzeyleri Arasındaki İlişkinin İncelenmesi. Beden Eğitimi ve Spor Bilimleri Dergisi, 11(1): 109-117.

DENIZ, Serkan; ÇİMEN, Mesut ve Onur YÜKSEL (2020). Psikolojik sağlamlığın iş stresine etkisi: Hastane çalışanlarına yönelik bir araştırma. Sakarya Üniversitesi, İsletme Bilimi Dergisi (JOBS), 8(2), 351-370.

DOĞAN, Tayfun (2015). "Kısa Psikolojik Sağlamlık Ölçeği’nin Türkçe Uyarlaması: Geçerlik ve Güvenirlik Çalışması", The Journal of Happiness \& Well-Being, 3(1): 93-102.

DOĞAR, Nizamettin (2013). Kişilik, Örgütsel Bağlllık ve İş Tatmini Arasındaki İlişkilerin İncelenmesi: İstanbul'da Faaliyet Gösteren İki Ticarî Bankada Bir Araştırma (Yayımlanmamış Doktora Tezi), Çukurova Üniversitesi Sosyal Bilimler Enstitüsü, Adana.

DOLBIER, C. L., SMITH, S. E. \& STEINHARDT, M. A. (2007). Relationships of Protective Factors to Stress and Symptoms of Illness. American Journal of Health Behavior, 3(4), 423433

ERDOĞAN, Emine (2015). Tanrı Alg1sı, Dini Yönelim Biçimleri ve Öznel Dindarlığın Psikolojik Dayanıklllıkla İlişkisi: Üniversite örneklemi. Mustafa Kemal Üniversitesi Sosyal Bilimler Enstitüsü Dergisi, 12(29), 223-246 
ERKOÇ, Beyza ve M. Zafer, DANIŞ (2020). Üniversite Öğrencilerinin Psikolojik Sağlamlık Düzeylerinin Tespit Edilmesine Yönelik Bir Araştırma. Korklareli Üniversitesi Sosyal Bilimler Dergisi, 4(1), 34-42.

EYSENCK, H. J. \& G. WILSON (2000). Kişiliğinizi Tanyzn. İstanbul: Remzi Kitabevi.

FAYOMBO, Grace A. (2010). "The Relationship Between Personality Traits and Psychological Resilience Among the Caribbean Adolescents", International Journal of Psychological Studies, 2(2): 105-116, doi:10.5539/ijps.v2n2p105

FLETT, Gordon L. (2007). Personality Theory \& Research: An İnternational Perspective. Canada: Mississauga: J. Wiley and Sons.

Fraenkel,, J. R., Wallen, N. E. \& Hyun, H. H. (2012). How to Design and Evaluate Research in Education. New York, NY: McGraw Hill Education

FRASER, M.W.; GALINSKY, M. J. \& J. M. RİCHMAN (1999). "Risk, Protection, and Resilience: Toward a Conceptual Framework For Social Work Practice”, Social Work Research, 23(3): 131-143.

FRIBORG, O.; BARLAUG, D.; MARTINUSSEN, M.; ROSENVINGE, J. \& O. HIJEMDAL (2005). "Resilience in Relation to Personality and İntelligence", International Journal of Methods in Psychiatric Research, 14(1): 29-42.

FROUTAN, R.; MAZLOM, R.; MALAKZADEH, J. \& A. MIRHAGHİ (2018). "Relationship Between Resilience and Personality Traits in Paramedics", International Journal of Emergency Services, 7(1): 4-12. doi:10.1108/ijes-12-2016-0028

GENÇ, Alper (2014). Psikolojik Dayanıklılı̆̆ın Örgütsel Bağllıı ve İşten Ayrılma Niyetine Etkisi: Görgül Bir Araştırma, (Yayımlanmamış Yüksek Lisans Tezi), Başkent Üniversitesi, Sosyal Bilimler Enstitüsü Ankara.

GÖKMEN, Bülent (2014). Özel Eğitim Okulu Yöneticilerinin Psikolojik Dayanıklılık ve İş Doyumları Arasındaki İlişkinin İncelenmesi (İstanbul Örneği), (Yayımlanmamış Yüksek Lisans Tezi), İstanbul Aydın Üniversitesi Sosyal Bilimler Enstitüsü, İstanbul.

GÖKSAL, Mustafa (2017). Sınıf Öğretmenlerinin Beş Faktör Kişilik Özellikleri ile Örgütsel Vatandaşlık Davranışları Arasındaki İlişkinin İncelenmesi (Yayımlanmamış Yüksek Lisans Tezi), Mersin Üniversitesi Eğitim Bilimleri Enstitüsü, Mersin.

GREENE, Roberta. (2002), Human behavior theory: A resilience orientation. In Greene R. editor. Resiliency: An integrated approach to practice, policy, and research. Washington, DC: NASW Press: 1-28.

GUINN, B.; VINCENT, V. \& D. DUGAS (2009), "Stress Resilience Among Border Mexican American women", Hispanic Journal of Behavioral Sciences, 31(2): 228-243. doi: $10.1177 / 0739986309332003$

HOŞOĞLU, Rümeysa; KODAZ FIRINCI, Aynur, BINGÖL YILMAZ, Tuğba ve Meryem VURAL BALTIK (2018). Öğretmen Adaylarında Psikolojik Sağlamlık. Uluslararası Toplum Arassttrmalar Dergisi, 8(14), ISSN:2528-9527 E-ISSN: 2528-9535

KANDEMİ, Ayșe (2019). Psikoloji Öğrencilerinin Psikolojik Sağlamlık, Duygusal Zekâ ve Kişilik Özellikleri Açısından İncelenmesi (Yayımlanmamış Yüksek Lisans Tezi), Hasan Kalyoncu Üniversitesi Sosyal Bilimler Enstitüsü, Gaziantep.

KARAKIŞ, Sevim (2019) Kamu Hastanelerinde Çalışan Hemşirelerin Afetlere Hazır Oluşluk Durumları ve Psikolojik Sağlamlıkları (Yayımlanmamış Yüksek Lisans Tezi), Marmara Üniversitesi, Sağllk Bilimleri Enstitüsü, İstanbul 
KILIÇ, Şenay D. (2014). Üniversite Öğrencilerinin Yalnızlık ve Psikolojik Dayanıklılıklarının İncelenmesi. (Yayımlanmamış Yüksek Lisans Tezi), Atatürk Üniversitesi, Eğitim Bilimleri Enstitüsü, Erzurum.

KIRIMOĞLU, Hüseyin; FILAZOĞLU ÇOKLUK, Gülşen ve Yunus YILDIRIM (2012). “Türk Antrenörlerin Y1lmazlık Düzeylerinin İncelenmesi”, Elektronik Sosyal Bilimler Dergisi, 11 (39): 115-127.

KIRIMOĞLU, Hüseyin; YILDIRIM, Yunus ve Ali TEMIZ (2010), “İlk ve Ortaöğretim Okullarında Görev Yapan Beden Eğitimi ve Spor Öğretmenlerinin Yilmazlık Düzeylerinin İncelenmesi (Hatay İli Örneği)", Niğde Üniversitesi Beden Eğitimi ve Spor Bilimleri Dergisi, 4 (1): 88-97.

KÖKNEL, Özcan (2005). Kişilik. İstanbul: Altın Kitaplar Yayınevi

LIU, Y., WANG, Z. \& LI, Z. (2012). "Affective Mediators of the Influence of Neuroticism and Resilience on Life Satisfaction", Personality and Individual Differences, 52, 833-838.

LUTHAR, S.S.; CİCCHETTI, D. \& B. BECKER (2000). "The Construct of Resilience: A Critical Evaluation and Guidelines For Future Work”, Child Development, 71(3): 543-562.

MADDI, S.; R.; HARVEY, R.H.; KHOSHABA, D.M.; LU, J.L., PERSICO, M. \& M. BROW (2006). "The Personality Construct Of Hardiness, III: Relationships with Repression, Innovativeness, Authoritarianism, and Performance", Journal of Personality, 74(2): 575-598.

MASTEN, A. S. \& J.D. COATSWORTH (1998)." The Development of Competence in Favorable and Unfavorable Environments", American Psychological Association, 53(2): 205-220. doi:10.1037/0003-066x.53.2.205

METIN, Mustafa. (2014). Kuramdan Uygulamaya Eğitimde Bilimsel Araștırma Yöntemleri. Ankara: Pegem Akademi Yayınclik.

NAKAYA, M.; OSHIO, A.\& H. KANEKO (2006). "Corelations for Adolescent Resilience Scale With Big Five Personality Tratits", Psychological Reports, 98(3): 927-930. doi:10.2466/pr0.98.3.927-930

NOYAN, Handan ve Özlem SERTEL- BERK (2007). "Ergenlerde Sosyal Fobi, İçe ve Dışa Dönük Kişilik Özellikleri ve Okul Başarı Durumu”, Psikoloji Çalışmalar Dergisi, 27:31-50.

OKTAY, Handan (2007). İlköğretim ve Ortaöğretim Kurumlarında Çalışan Öğretmenlerin Motivasyonu ve Kişilik Özellikleri Arasındaki İlişkinin İncelenmesi (Yayımlanmamış Yüksek Lisans Tezi). Yeditepe Üniversitesi Sosyal Bilimler Enstitüsü, İstanbul.

OSHIO, A.; TAKU, K.; HİRONA, M. \& G. SAEED (2018). "Resilience and Big Five Personality Traits: A Metaanalysis", Personaliy and Individual Differences, 127: 54-60.

ÖZER, Esin. (2013). Üniversite Öğrencilerinin Psikolojik Sağlamlık Düzeylerinin Duygusal Zekâ ve Beş Faktör Kişilik Özellikleri Açısından İncelenmesi (Yayımlanmamış Doktora Tezi), Konya Necmettin Erbakan Üniversitesi, Eğitim Bilimleri Enstitüsü, Konya.

SAHİ, Mahima (2016). "A Study of Personality in Relation to Resilience and Stress", International Journal for Innovation Education and Research, 4(2): 10-18.

SARWAR, M., INAMULLAH, H., KHAN, N. \& ANVWAR, N. (2010).” Resilience and academic achievement of male and female secondary level students in Pakistan". Journal of College Teaching \& Learning, 7(8), 19-24.

SAVİ, Firdevs (2008). 12-15 Yaş Arası İlköğretim Öğrencilerinin Davranış Sorunları ile Aile İşlevleri ve Anne Baba Kişilik Özellikleri Arasındaki İlişkinin İncelenmesi, (Yayımlanmamış Doktora Tezi), Dokuz Eylül Üniversitesi Eğitim Bilimleri Enstitüsü, İzmir. 
SELÇUKLU, Almila E. (2013). Örgütsel Bağlıllğın Bir Yordayıcısı Olarak Kurum Kültürü ve Psikolojik Dayanıklılık, (Yayımlanmamış Yüksek Lisans Tezi), Erciyes Üniversitesi Eğitim Bilimleri Enstitüsü, Kayseri.

SEVI, Emine S. (2009). Psikobiyolojik Kişilik Modeli ve Beş Faktör Kişilik Kuramı: Mizaç ve Karakter Envanteri (TCI) ile Beş Faktör Kişilik Envanterinin (5FKE) Karşılaştırılması (Yayımlanmamış Yüksek Lisans Tezi), Ege Üniversitesi Sosyal Bilimler Enstitüsü, İzmir.

SEZGIN, Ferudun (2009). "Relationships Between Teacher Organizational Committment, Psychological Hardiness and Some Demographic Variables in Turkish Primary Schools," Journal of Educational Administration, 47(5): 630-651.

SEZGİN, Ferudun. (2012). "İlköğretim Okulu Öğretmenlerinin Psikolojik Dayanıklılık Düzeylerinin İncelenmesi”, Kastamonu Ë̆itim Dergisi. 20(2): 489-502.

SILLS L. C.; SHARON C. \& S. MURRAY (2006). "Relationship of Resilience to Personality, Coping and Psychiatric Symptpoms in Young Adults", Behaviour Research and Therapy, 44: 585-599.

SOYER, Fikret; GÜLLE, Mahmut; MIZRAK, Orcan; ZENGIN, Serkan ve Erdi KAYA (2013). "Spor Yapan Bedensel Engelli Bireylerin Çeşitli Değişkenlere Göre Yılmazlık Düzeylerinin İncelenmesi”, Niğde Üniversitesi Beden Eğitimi ve Spor Bilimleri Dergisi, 7 (2): 126-136.

ŞAHİN, Gönül (2020). Öğretmenlerin Kişilik Özellikleri ile Atılganlıkları Arasındaki İlişkide Pozitif Sermayenin Aracı Rolü, (Yayımlanmamış Doktora Tezi), Hacettepe Üniversitesi Eğitim Bilimleri Enstitüsü. Ankara.

ŞEKER-SIR, Nilüfer. (2016). Öğretmen Adaylarının 5 Faktör Kişilik Kuramına Göre Kişilik Özelliklerinin Belirlenmesi ve Bazı Değişkenlere Göre İncelenmesi (Yayımlanmamış Yüksek Lisans Tezi), Yıldız Teknik Üniversitesi, Sosyal Bilimler Enstitüsü, İstanbul.

TAŞĞIN, Özden., BOZGEYİKLİ, Hasan ve Emre. E. BOĞAZLIYAN (2017). Üniversiteli Gençlerin İşsizlik Kaygıları ile Psikolojik Dayanıklılıkları Arasındaki İlişki. HAK-İS Uluslararası Emek ve Toplum Dergisi, 6(15), 551-567.

TEKİN, Emel (2011). Askeri Hastanelerde Çalışan Hemşirelerin Psikolojik Dayanıklılık ve Tükenmişlik Düzeylerinin Belirlenmesi, (Yayımlanmamış Yüksek Lisans Tezi), Gazi Üniversitesi Sağlık Bilimleri Enstitüsü, Ankara.

TERREL, H. K.; HILLL, E. D. \& C. T. NAGOSHİ (2008)." Gender Differences in Aggression: The Role of Status and Personality in Competitive Interactions", Sex Roles, 59: 814-26.

TOPÇU, Feyza (2017). Üniversite Öğrencilerinin Psikolojik Dayanıklılık Düzeylerinde Beş Faktör Kişilik Özelliklerinin Yordayıcı Etkisinin İncelenmesi (Yayımlanmamış Yüksek Lisans Tezi), Fatih Sultan Mehmet Vakıf Üniversitesi, Sosyal Bilimler Enstitüsü, İstanbul.

TOPRAK, Handan (2014). Ergenlerde Mutluluk ve Yaşam Doyumunun Yordayıcısı Olrak Psikolojik Sağlamlık ve Psikolojik İhtiyaç Doyumu (Yayımlanmamış Yüksek Lisans Tezi). Sakarya Üniversitesi Eğitim Bilimleri Enstitüsü. Sakarya.

TUNÇ, Erhan ve Ramin ALIYEV (2015). "Lisansüstü Öğrencilerinin Kişilik Özelliklerinin İncelenmesi”, Gaziantep University Journal of Social Sciences, 14(4): 949-963.

TÜRKER YILDIZ, Nesrin. (2018). Yetişkinlerde Dindarlık ve Psikolojik Sağlamlık İlişkisi Üzerine Bir Araştırma (Yayımlanmamış Yüksek Lisans Tezi), Uludağ Üniversitesi Sosyal Bilimler Enstitüsü, Bursa.

UĞURLU, Baran ve Nurhayat ÇELEBİ (2014). "Resmi Liselerde Çalışan Öğretmenlerin Kişilik Özelliklerinin Demografik Değişkenlere Göre İncelenmesi”, Adiyaman Üniversitesi Sosyal Bilimler Enstitüsü Dergisi, 7(18): 537-569, (https://doi.org/10.14520/adyusbd.835). 
YAZICI ÇELEBİ, Gülin (2021). “Kadınların Kişilik Özellikleri ile Psikolojik Sağlamlık Düzeyleri Arasındaki İlişkinin İncelenmesi”, Mavi Atlas, 9(1): 132 - 146

ÜLKER TÜMLÜ, Gamze ve Ergün RECEPOĞLU (2013). "Üniversite Akademik Personelinin Psikolojik Dayanıklılık ve Yaşam Doyumu Arasındaki İlişki”, Yükeseköğretim ve Bilim Dergisi, 3: 205-213, DOI: 10.5961/jhes.2013.078.

YANBASTI, Gülgün (1990). Kişilik Kuramlarr. İzmir: Ege Üniversitesi Basımevi. 